\title{
Methodological Consideration of Various Intraosseous and Heterotopic Bone Grafts Implantation in Animal Models
}

\author{
Weiguo $\mathrm{Xu}^{1}$, Gerald Spilker ${ }^{1}$ and Christian Weinand ${ }^{1,2 *}$ \\ ${ }^{1}$ Department of Plastic and Reconstructive Surgery, University Hospital of Witten- Herdecke, Cologne Merheim, Germany \\ ${ }^{2}$ Department of Plastic and Aesthetic Surgery, Hand Surgery, Burns, Dietrich-Bonhoeffer-Klinikum, University of Greifswald, Neubrandenburg, Germany
}

\begin{abstract}
Bone fracture healing is a complex process including inflammation, repair and remodeling. Bone grafts or substitute are widely accepted to treat impaired healing. Newly developed bone substitutes must undergo in vitro and in vivo testing before clinical application. All kinds of intraosseous and heterotopic implant models in small and/ or large animals are used for different bone substitutes. Orthotopic implant at models is used for evaluation of graft materials. Based on the statistic of literatures, we find small animals should be used first before large animal as osseous defect models. Rabbit and rat are the commonly chosen animals, while femur and calvaria are the most implanted anatomic sites.

Critical size defect models are useful as bone defect model, but vary considerably between animals. Typical heterotopic ossification after implantation of bone substitute is found almost in all species of animals. No bone formation is found after subcutaneous implantation of bone granule grafts in small animal, but in large animal. In contrast, bone block grafts show a distinguished result of bone formation in small animals as well as in large animals. This article reviews currently animal bone defect models and anatomic implant site for bone graft, gives a recommendation for the future research.
\end{abstract}

Keywords: Implant design; In vivo; Orthopaedic; Tissue engineering

\section{Bone Substitutes}

Developments in material technology offer clinicians a variety of choices of bone substitutes for patients. Usually, bone graft materials are divided into four categories, e.g., autograft, allograft, alloplast and xenograft. The application of autolougs bone grafting is gold standard in the therapy in bone defects by trauma, tumour resection, dental augmentation or osteonecrosis, although there are always potential risk and complications [1]. Allografts are taken from the same species with a different genotype, which have been treated by sterilization and antigenic procedures. There are several types of allografts: fresh or fresh frozen, freeze-dried and demineralised freeze-dried allograft [2]. Because of disease transmission, fresh allograft is not so frequently used [3]. On the basis of the development of material science, different kinds of alloplastic implant materials can be chosen by physicians as alternative. Most alloplastic implant materials are ceramics. They have several advantages: biocompatibility, non-antigenicity, lack of inflammatory response and resorbability, etc. [4]. Silicone implants have been most frequently used for chin and finger implants. In the last three decades, allograft based on hydroxyapatite and/or silicon has been widely used in orthopedic and dental areas, because of its osteoconductive capacity [5]. Xenografts are taken from another species, which have the same composition and identical morphology compared to that of human bone. But the surface antigens of xenograft may cause immunogenic response. Bovine bone was chosen as xenograft materials because of simple source and low cost [6].

Because the supply of autologous bone grafts is limited in clinic, allogenic and xenogenic bone substitutes are quickly developed. The ideal bone substitute should have characteristics of biocompatibility, osteoactivity and biodegradation [7,8]. Other desirable characteristic include mechanical stability, optimized scaffold and vascularisation, biologically appropriate chemistry and surface charge, unlimited availability and structural stability [9]. Biocompatibility means that bone graft materials do not release chemical toxic substances or cause immunological, allergic or other adverse reactions in the recipient organism. Different methods in the ISO 10993-11 series of international norms are described to evaluate the biocompatibility of biomaterials [10].

Osteoactivity refers to the osteointegrative, osteoconductive, osteoinductive and osteogenic properties of an implant [11]. Osteointegration shows the capacity of bone graft direct binding to the surface of human bone without the growth of fibrous tissue at the bone-implant interface. Osteoconduction describes a bone substitute material supporting newly formed bone growth over its defined surface. Osteoinduction is the formation of new bone by active recruitment of mesenchymal stem cells from the surrounding tissue of the recipient. These stem cells differentiate into osteoblasts. This process is controlled by growth factors such as the bone morphogenetic proteins (BMP). Furthermore, BMP-incorporated bone implant material is applied in clinic [12]. Osteogenic properties refer to implants containing live cells, which contribute synthesis of new bone [13].

Implanted bone materials should be resorbed at a rate corresponding to new bone formation. Through the remodelling phase, biomaterials are replaced by new bone tissue [14]. Mechanical stability of the material provides adequate strength and mechanical stability according to the bone defect [15]. Vascularisation with sufficient blood supply is necessary for new bone formation and bone remodelling [16]. A high level of porosity and interconnection of pores in the material provides

*Corresponding author: Christian Weinand, Department of Plastic and Aesthetic Surgery, Hand Surgery, Burns, Dietrich-Bonhoeffer-Klinikum, University of Greifswald, Neubrandenburg, Germany, Tel: +49 395775 2802, E-mail: chwscot@yahoo.com

Received August 12, 2015; Accepted December 09, 2015; Published December 17, 2015

Citation: Xu W, Spilker G, Weinand C (2015) Methodological Consideration of Various Intraosseous and Heterotopic Bone Grafts Implantation in Animal Models. J Tissue Sci Eng 6: 161. doi:10.4172/2157-7552.1000161

Copyright: (c) $2015 \mathrm{Xu} \mathrm{W}$, et al. This is an open-access article distributed under the terms of the Creative Commons Attribution License, which permits unrestricted use, distribution, and reproduction in any medium, provided the original author and source are credited. 
a larger surface so that autologous proteins from the blood enter the nanopores and cover the entire inner surface $[17,18]$.

Following the development of nanotechnology, some new bioactive nanohydroxylapatite are widely applied in bone tissue engineering, whose composition and crystal structure is very close to natural bone [19]. For example, a fully synthetic nanocrystalline hydroxyapatite embedded in a matrix of silica gel (NanoBone) has showed new bone formation after five weeks while demonstrating degradation of materials [20]. Currently, there is no ideal material bone graft that can provide all requirements of bone defect in different defect site. Nevertheless, they provide certain advantages, such as good store, ready availability and the prevention of a further operation for patient. Furthermore, all kinds of bone substitutes have also been applied as cellular scaffolding system [21]. Cell-based bone graft substitute have shown significant osteogenic potential in animal segmental bone defect [22].

\section{Experimental Animal Choices for Evaluation of Bone Substitutes}

New developed bone replacement material needs strictly test in vitro and in vivo due to cytotoxicity and physical and chemical characterise before clinical applications for human [23]. Before beginning animal experiment, biomaterial should be at first tested by cell culture in vitro for cytotoxicity and cytocompatibility. Basic demand of a bone substitute material for in vitro cell culture is that the bone graft supports cell attachment, proliferation and migration [24]. A variety of experimental animal species including mouse $[25,26]$, rat $[27,28]$, rabbit $[29,30], \operatorname{dog}[31]$, pig [32] and goat [33] have been used to test bone grafts. Although most animal models are in quadrupeds and may not model the load bearing conditions evident with bipedal humans. But bone structure, composition and biology of large animal (i.e., dog, sheep, pig and goat) are very similar to that of human bone, which demonstrated a very similar bone healing process compared with human bone remodelling [34]. On one hand, the use of bone defects in large animal models is highly recommended to clearly evaluate the capacity of the tissue-engineered bone substitute for its final clinical application. On the other hand, using large animal models has two major limitations, for example, high costs and the care for the respective animals. Therefore, $38 \%$ of the studies in bonehealing research already preferred the rat as the experimental animal, following the next rabbit $19 \%$, mouse $15 \%$, sheep $11 \%$, dog $9 \%$, goat $4 \%$ and other $4 \%$ [35]. That means above $70 \%$ experiment animal species are small animal (rat, rabbit and mouse). Therefore, Le Guehennec and co-workers suggested that small animals should be a prerequisite before preclinical implantation of bone substitutes in large animals [36]. Small animal approach using rats or mouse allows easily studying a reasonable number of animals at different time points. In a dorsal skinfold chamber model of mouse, the inflammatory and angiogenic host tissue response to biomaterial can be on-line given for evaluation of biocompatibility and vascularisation in vivo [37]. Selection of animal species should be decided by purpose of research, clear questions and experimental conditions [38]. Otherwise, due to various anatomic, biochemical, and gene expression of experiment animals, the same animal model used in different species may show conflicting results in bone healing studies [39].

\section{Intraosseous Critical/Noncritical Defect and Heterotopic Implant Model}

Various animal models and implantation sites are applied to test bone substitutes by means of different evaluations of parameters [40]. There is the fundamental distinction between intraosseous and heterotopic models for bone substitute materials. An intraosseous model allows analysis of osteoactivity and biodegradation of implanted materials in a bone environment [41]. The application of heterotopic implant model is gold standard for assessment of the biocompatibility as well as the osteogenic and osteoinductive potential of bone graft materials [42].

Using intraosseous model, bone graft materials are usually implanted in tibia [43], femur [44], ulna [45] and calvaria defect [46]. According to the size of the defect, in which the bone substitute will be implanted, they can be categorized as either critical or noncritical defects. A critical size defect is a segmental or drill whole defect with load or non-load mechanical stress, which does not heal spontaneously during the lifetime without pathological changes [47]. Frequently, segmental critical/noncritical size defect was chosen in animal models for testing functionality of bone substitute materials. Such defects are usually used to evaluate whether the bone graft material is in a position to bridge the defect [48]. The drill hole critical/noncritical defect is usually used to study a variety of bone defects and potential therapies designed to repair these bone defect, which is applied to test filling materials for bone defect [49].

By means of heterotopic implant model, the toxicity and carcinogenic effect of biomaterials could be also evaluated by direct contact with the subcutaneous and muscular tissue [50]. Cellularity and vascularity of the recipient bed are very important parameters for the osteoinductive capacity in the ectopic bone formation [51]. Subcutaneous and muscular implantation usually allows for an evaluation of the biocompatibility, angiogenesis, degradation and osteoinduction of the tested materials [52]. Using subcutaneous implant model in rat, dynamical changes are investigated after implantation of nanostructured hydroxyapatite until 12 days [53].

Lots of studies demonstrated that adipose tissue is a good source of adult stem cells with a multilineage differentiation potential, for example, bone, cartilage, skeletal muscle and other cell types [54]. Comparing to muscle tissue, adipose tissue is well-vascularized with a capillary density [55]. Hartman et al. reported that no significant difference existed between intramuscular and subcutaneous recipient sites after bone substitute implantation [56]. However, this method ultimately does not analyse the functionality of a bone substitute material, because subcutaneous tissue has different physiological structure and molecular biological reaction to implanted material compared to osseous environment [57]. Furthermore, new bone formation in heterotopic tissue does not provide information on the influence of biomechanical stress and dynamic load as intraosseus implantation [58].

In this review, we examined the literature relating to intraosseous and heterotopic model used large and small animal in the evaluation of bone substitute.

\section{Bone Defect Model and Different Anatomical Sites for Implantation in Animals}

Different species of experimental animals and defect models are applied in bone tissue engineering, but there have been little criteria for choice of animal and implantation site. Following rapid development of materials science, more and more new bone grafts are tested by means of experimental animals.

We have summarised literatures of the MEDLINE database during 1 January 2006 through 30 November 2015 for studies published about bone substitutes using bone defect models in different animals. In all 


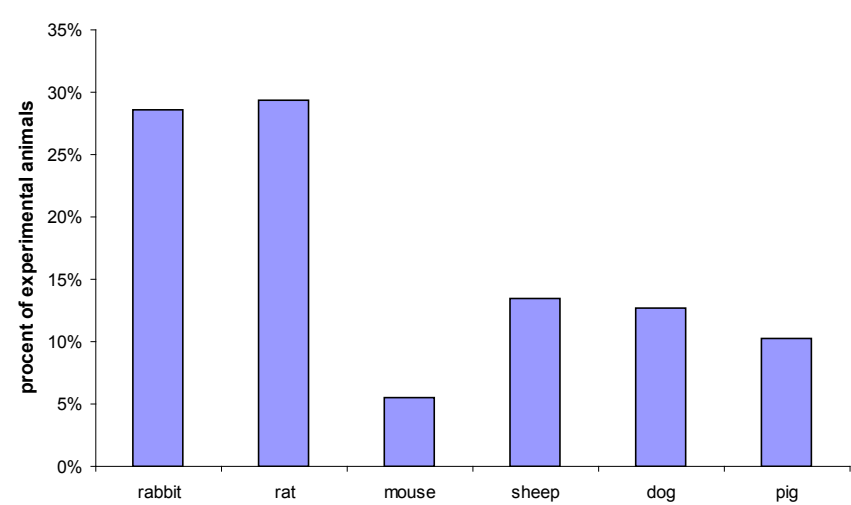

Figure 1: Quantitative statistic representing choices of various animals in bone defect models as derived from publications in pubmed over last fifteen years. Rat and rabbit have been the most widely used animals for such studies.

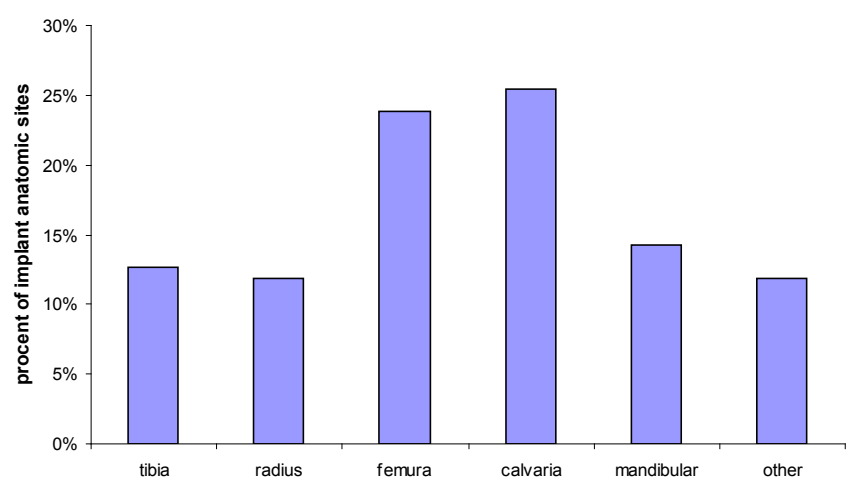

Figure 2: Distribution of anatomic sites for bone defect model, calvaria and femur are the most used region for bone graft implantation.

\begin{tabular}{|l|c|c|c|c|c|}
\hline & tibia & radius & femur & $\begin{array}{c}\text { clavaria } \\
\text { (diameter) }\end{array}$ & mandibular \\
\hline rabbit & $8[59]$ & $15[60]$ & $15[61]$ & $20[62]$ & $15 \times 10[63]$ \\
\hline rat & $5[64]$ & $5[65]$ & $6[66]$ & $8[47]$ & 5 (diameter) [67] \\
\hline mouse & NA & NA & $5[68]$ & $4[69]$ & 4 (diameter) [70] \\
\hline sheep & $50[71]$ & NA & $25[72]$ & $22[73]$ & 35 (diameter) [74] \\
\hline dog & NA & $25[75]$ & $21[76]$ & $20[47]$ & $18 \times 10[77]$ \\
\hline pig & $20[23]$ & NA & NA & $9[78]$ & $50[79]$ \\
\hline
\end{tabular}

Table 1: Summary of critical size defect $(\mathrm{mm})$ in different anatomic site of animals $\mathrm{NA}=$ not available. experimental animals for bone defect models, $64 \%$ of all animals used were small animals. The small animals commonly chosen for bone defect models are rat (29\%) and rabbit (29\%). Mice are only used in about $6 \%$ of all cases, because of their difficult management (Figure 1). Among big animals, sheep, dog and pig dominate at almost the same ratio of $10 \%$ to $13 \%$ (Figure 1 ).

Bone grafts are made into different shapes in order to apply for different defect size and shape. Therefore, there is no established standard for anatomical implantation sites. However, independent from the animal employed in the experiments, long bones (49\%) such as tibia (13\%), radius (12\%) and femur (24\%) are commonly chosen as implantation region. Viateav states that the calvaria mimic the clinical bone defect environment best because of poor blood supply and presence of little bone marrow. Furthermore, calvarial bone is formed by intramembranous ossification rather than endochondral ossification [42]. Therefore, the calvarial defect model rate is as high as $25 \%$ of all defects used. Interestingly, bone grafts and implants currently applied in craniofacial surgery are increasing in number. In coherence with this tendency, mandibular defect model are found in literature in $14 \%$ of all cases. Other anatomic sites, such as the iliac, rib, ulna and spinal region, are used in about $12 \%$ of all cases (Figure 2).

\section{Critical Size Defects of Animal Interaosseous Model in Different Anatomical Sites}

Multiple critical size defects of animal models have been performed to mimic bone defect environment for evaluation of bone grafts. In the following table, critical size defect in different anatomic sites of animals are summarized (Table 1).

A critical defect size is associated with the size of the animal and anatomical site of bone. Reproducible critical size defect model is very important for study design. However, numerous studies in vivo demonstrated that sizes of critical defects in the same species vary strongly from study to study [59]. In addition, researchers must consider that many systemic factors such as age, sex, endocrine and pharmacological status of animal strain could affect results [60].

\section{Heterotopic Model in Small and Large Animal Model}

There are no standard criteria for intramusclular and subcutaneous implantations. Abdomen, back, limb and neck are popular regions for implant. In addition, the variety in different bone substitutes makes comparison difficult as each bone graft has specific weight, density and volume. The following table provides an overview of some publications about bone grafts implanted either subcutaneous or intramuscular (Table 2).

\begin{tabular}{|c|c|c|c|c|c|}
\hline & Bone graft & Anatomic site & Observation period & Bone formation & References \\
\hline \multirow[t]{2}{*}{ rabbit } & PLGA/Type-I collagen+osteoblast & subcutaneous & 4 weeks & + & 82 \\
\hline & nanohydroxylapatite/polyamide block & intramuscle & 4 weeks & + & 83 \\
\hline \multirow[t]{3}{*}{ rat } & NanoBone granulate & subcutaneous & 6 months & - & 84 \\
\hline & Cortical bone cylinders & subcutaneous & 4 weeks & + & 85 \\
\hline & Hydroxyapatite/demineralized bone matrix & intramuscle & 8 weeks & + & 86 \\
\hline \multirow[t]{2}{*}{ mouse } & beta-tricalcium phosphate block & subcutaneous & 6 weeks & + & 87 \\
\hline & Human demineralized bone matrix & intramuscle & 8 weeks & + & 88 \\
\hline \multirow[t]{2}{*}{ sheep } & macroporous cement & subcutaneous & 6 months & - & 89 \\
\hline & calcium phosphate ceramics & intramuscle & 6 months & + & 90 \\
\hline \multirow[t]{2}{*}{ dog } & beta-tricalcium phosphate & subcutaneous & 12 weeks & + & 91 \\
\hline & HA/TCP biphasic ceramics & intramuscle & 15 months & + & 92 \\
\hline \multirow[t]{2}{*}{ pig } & nanocrystalline hydroxyapatite & subcutaneous & 8 months & + & 93 \\
\hline & tricalcium phosphate & intramuscle & 12 weeks & + & 94 \\
\hline
\end{tabular}

Table 2: Typical examples of subcutaneous and intramuscular implantation in different animals. 


\begin{tabular}{|c|c|c|c|}
\hline & Methods & Description & Reference \\
\hline \multirow{3}{*}{ histomorphometry } & histology & $\begin{array}{l}\text { biocompatibility, osteoactivity, } \\
\text { biodegradation }\end{array}$ & 104 \\
\hline & histochemistry & biochemical property & 105 \\
\hline & immunohistology & molecule identification & 106 \\
\hline \multirow{3}{*}{ radiography } & X-ray & densitometry & 107 \\
\hline & micro-computed tomography & morphological characterization, quantitative assessment & 108 \\
\hline & computed tomography & in situ evaluation & 109 \\
\hline biomechanical test & $\begin{array}{c}\text { torsional stiffness, shear stress, } \\
\text { angel of fracture }\end{array}$ & mechanical strength & 110 \\
\hline \multirow{3}{*}{ microscopy } & scanning electron microscopy & morphologic characterization & 111 \\
\hline & transmission electron microscopy & ultrastructural morphology & 112 \\
\hline & energy dispersive X-ray spectroscopy & physiochemical characterization & 113 \\
\hline
\end{tabular}

Table 3: Methods selected in bone scaffold evaluation.

Herein, we give only some examples of heterotopic implant model. Many factors, for example chemical component and physical characters, size of implanted biomaterial and observation period can influence results. Interestingly, our previous work showed granule grafts did not induce bone formation in small animals, but block grafts induced bone formation in small animals. Yuan et al confirmed that material-induced bone formation depends on the animal species and implanted material [61]. Likewise, various bone graft combining growth factor or stem cells shows different osteogenic properties in various heterotopic models [62-65].

Mechanics of heterotopic ossification is not completely clarified. Kan et al demonstrated that morphogenetic protein (BMP) plays a crucial role in this case [66]. Heterotopic implantation induces hyperactivities of BMP receptors. Osteoinductive properties of BMP are reported first time by Urist et al $[67,68]$. Now recombinant BMPs (rBMPs) have been widely applied for treatment of spinal fusions, nonunion fractures, craniomaxillofacial and periodontal bone defects, and bone/tooth implant augmentation [69], as they are readily available.

\section{Methodical analyse of bone graft after implantatation in animal}

Bone grafts are made of a variety of components, structures, shapes and sizes; there are no established standard methods for analysing bone substitute in vivo. However, most often used methods are radiological evalution using $\mathrm{x}$-rays, mikro $\mathrm{CT}$, or high resolution $\mathrm{CT}$ as well as histochemical or immunohistochemical analysis. The most often used methods are visualized in Table 3 .

\section{Discussion}

Ideal bone substitutes should support osteogenesis, osteointegration, osteoconduction and osteoinduction and contain or propagate the ingrowth of osteoblast or osteoprogenitor stem cells. However, only autologous bone graft has, as mentioned above, these properties. During the past 30 years different bone grafts have been developed to provide structural stability in order to overcome the clinical drawbacks associated with bone defects.

Currently, all kinds of bone grafts including natural bovine-derived hydroxyapatite and hydroxyapatite or silicon based bone substitute are widely applied in clinic. As synthetic material mimics' composition and structure of extracellular bone matrix and can be customized for specific application without the limit of amount supply, this is especially interesting for clinical application in orthopedic surgery [70]. Using 3D based imaging of defect positions, biomodels can be produced ahead of operation in reconstructive surgery with availability of different size and shape, thereby reducing operation time and patient trauma extremely and increasing the patient's safety [70-88]. All kinds of biomaterials combining BMP have shown successful effects in reconstructing long bones, spines and the facial skeleton defects [72-105].

Rational experimental design and careful selection of the animal model play a very important role in researching bone tissue engineering. No experiment model fulfils complete evaluation of new developed bone graft materials. A newly developed bone biomaterial should first be optimized in vitro [73,93-95,104]. After that, various parameters are further evaluated through small animal models [106-108]. In the next step, large animal models are used to test the practicability functionality of graft materials before clinical application [86,105,109-115]. For each specific question, a suitable animal model is needed. Each animal model has its own advantages and disadvantages. Intraosseous defect models are necessary to assess the possibility of clinical application for orthopaedic and craniofacial surgery. To evaluate biocompatibility, biodegradation and vascularisation, subcutaneous or intramuscular implantation models in mouse or rat are recommended $[22,42,69,46,73,82,84-86,88,90,93,94,96,100-103]$. But these models may not be suitable to answer questions of osteoinduction of granular bone grafts. A possible explanation for the difference between large and small animal in subcutaneous implantation of granule bone graft may be the increased micromovement in small animals $[73,82,84-$ $86,88,90,93,94,96,100]$. Small animals show constant and comparatively large movements of their body after implantation of granulated bone grafts compared to large animals $[104,105]$. Subcutaneous tissue in large animal provides relatively lesser movement of the subcutaneous tissue environment for implanted bone granules, which may be favourable for ectopic new bone formation. Another reason might be the increased stability of block scaffolds themselves compared to granules. Maybe granules tend to move easily with the environment, whereas block grafts remain stable and allow only micromovement on their surface. This might explain the increased bone formation on the surface around block scaffolds $[74,87]$. The micromovements might be too macro for osteocytes or stem cells to produce bone extracellular matrix in granules.

Recent development in tissue regeneration provided biomaterials for slow release of proteins over a period of time, thus giving cells continuous stimuli to differentiate into desired cells $[60,65,66,68,70,73,75,76,78,92,98-100,109,116-121]$. The level of gene expression in the surrounding tissue to regenerate bone can be enhanced by delivery of plasmid DNA using hydrogel microspheres, more than plasmid DNA solution. BMP -incorporated gelatin/ $\beta$-TCP scaffolds lead to significantly increased osteogenesis compared to the chem- 
Citation: Xu W, Spilker G, Weinand C (2015) Methodological Consideration of Various Intraosseous and Heterotopic Bone Grafts Implantation in Animal Models. J Tissue Sci Eng 6: 161. doi:10.4172/2157-7552.1000161

ical induced osteogenesis in specimens $[60,65,66,68,70,75,76,78,92,98$ $100,109,116-121]$. In previous studies, various groups showed a continuous release of BMP2 in vitro and in vivo $[65,66,68,70,73,75,76,92,98$ 100,109,119-121]. This suggests that the environmental chemical or humeral factors play an important role in the formation of bone and that bone formation can be orchestrated when using these factors.

In our table different animal model have been shown to support various sorts of bone regeneration. This different bone regeneration suggests that the different animals provide different chemical and humeral environment for cells, thereby influencing bone formation enormous. In addition, the site of implantation might also affect bone formation by providing different humeral or chemical environmental factors $[12,24,79-92,105]$

So far, regular X-ray examination, CT or quantitative CT scanners have been used to assess trabecular bone structure and bone mineral density. Good correlation between measured density values of trabecular bone and biomechanical properties have been demonstrated [79-81]. Although CT resolution has improved over time, three-dimensional evaluation of new bone formation requires different high-resolution methods. Recently ultra-high resolution volumetric CT scanning (VCT) has been shown to correctly analyse bone formation in tissue engineered constructs over the course of six weeks [22-32,60,65,66,68,70,71,73,75,76,92,98-100,109,116121]. A different approach to estimate the formation of new bone in small animals is the use of micro-CT scanners. However, a clinical application of these micro-CT scanners is very limited [22$27,65,66,68,70,71,73,75,109,116,117,119,120]$. But bone formation has to be concordant with radiographic imaging, as it was shown previously [71].

Histologically bone formation can be monitored. Here, regular histology must be differentiated from histochemistry or immunohistochemistry. All are being used to show bone formation, integration and osteoactivity. However, the use of the method depends on the aim of the researcher. Bone should also provide mechanical stiffness and withstand torsion. For evaluation of new bone formation, osteointegration into defects and mechanical strength ultimate tensile strength ( $\delta \mathrm{UTS})$, failure strain $(\delta \mathrm{f})$, fracture energy (Ef), and the dynamic tensile modulus $(\mathrm{M})$ can be tested biomechanically [2,5$13,18,22-32,60,65,66,68,70,71,73,75,109,116-120]$.

Using microscopy, structural changes can be monitored. Here, various methods have been applied such as scanning electron microscopy, transmission electron microscopy or energy dispersive $\mathrm{X}$-ray spectroscopy. Using light microscopy slides have to be stained to evaluate presence of bone. Regular histopathological staining for bone are van Kossa, alcain blue or alkaline Phosphatase, whereas the last is usually stained within the cells themselves and not within the extracellular matrix [22-32,60,67-69,71,73,75,90-102,105,109,116121]. When applying the scanning microscopy, tissue is characterised morphologically, transmission electron microscopy allows for ultrastructural morphological evaluation [22,60,75,90,105,116-120]. However, the tissue has to be prepared special, but structural analysis shows trabecular formation, integration into the surrounding bone stock or allows for very early proof of non-union. In combination with physiochemical characterization by dispersive X-ray spectroscopy analysis can be complete [82-85]. The drawback of microscopy is the invasive method to harvest bone or tissue material. Ideally, all methods are combined [71].

In conclusion, it is important for any animal study that many factors should be taken into account, when selecting the suitable species, the desire defect model and methods for evaluation.

\section{References}

1. Worm PV, Ferreira NP, Faria MB, Ferreira MP, Kraemer JL, Collares MV (2010) Comparative study between cortical bone graft versus bone dust for reconstruction of cranial burr holes. Surg Neurol Int 22;1:91.

2. Mah J, Hung J, Wang J, Salih E (2004) The efficacy of various alloplastic bone grafts on the healing of rat calvarial defects. Eur J Orthod 26:475-482.

3. Tomford WW (1995) Transmission of disease through transplantation of musculoskeletal allografts. J Bone Joint Surg Am 77:1742-1754.

4. Jordan DR, St Onge P, Anderson RL, Patrinely JR, Nerad JA (1992) Complications associated with alloplastic implants used in orbital fracture repair. Ophthalmology 99:1600-1608

5. LeGeros RZ (2008) Calcium phosphate-based osteoinductive materials. Chem Rev 108:4742-4753.

6. Accorsi-Mendonça T, Conz MB, Barros TC, de Sena LA, Soares Gde A Granjeiro JM (2008) Physicochemical characterization of two deproteinized bovine xenografts. Braz Oral Res 22:5-10.

7. Green D, Walsh D, Mann S, Oreffo RO (2002) The potential of biomimesis in bone tissue engineering: lessons from the design and synthesis of invertebrate skeletons. Bone 30:810-815.

8. Hutmacher DW, Schantz JT, Lam CX, Tan KC, Lim TC (2007) State of the art and future directions of scaffold-based bone engineering from a biomaterials perspective. J Tissue Eng Regen Med 1:245-260.

9. Puricelli E, Corsetti A, Ponzoni D, Martins GL, Leite MG, Santos LA (2010) Characterization of bone repair in rat femur after treatment with calcium phosphate cement and autogenous bone graft. Head Face Med 28;6:10.

10. Galia CR, Macedo CA, Rosito R, Mello TM, Camargo LM, Moreira LF (2008) In vitro and in vivo evaluation of lyophilized bovine bone biocompatibility. Clinics (Sao Paulo) 63:801-806

11. Moore WR, Graves SE, Bain GI (2001) Synthic bone graft substitutes. ANZ J. Surg 71:354-361.

12. Albrektsson T, Johansson C (2001) Osteoinduction, osteoconduction and osseointegration. Eur Spine J 10 Suppl 2:S96-101.

13. Zhang Y, Wu C, Friis T, Xiao Y (2010) The osteogenic properties of CaP/silk composite scaffolds. Biomaterials 31:2848-2856.

14. Kihara H, Shiota M, Yamashita Y, Kasugai S (2006) Biodegradation process of alpha-TCP particles and new bone formation in a rabbit cranial defect model. $J$ Biomed Mater Res B Appl Biomater 79:284-291.

15. Dvorak G, Reich KM, Tangl S, Goldhahn J, Haas R, Gruber R (2011) Cortical porosity of the mandible in an osteoporotic sheep model. Clin Oral Implants Res 22:500-5.

16. Albrektsson $T$ (1980) The healing of autologous bone grafts after varying degrees of surgical trauma. A microscopic and histochemical study in the rabbit. J Bone Joint Surg Br. 62:403-410.

17. Yoshikawa H, Tamai N, Murase T, Myoui A (2009) Interconnected porous hydroxyapatite ceramics for bone tissue engineering. J R Soc Interface. 6 Suppl 3:S341-348.

18. Bienengräber V, Gerber T, Henkel KO, Bayerlein T, Proff P, Gedrange T (2006) The clinical application of a new synthetic bone grafting material in oral and maxillofacial surgery. Folia Morphol (Warsz) 65:84-88.

19. Salata $O$ (2004) Applications of nanoparticles in biology and medicine. $J$ Nanobiotechnology 30;2:3.

20. Kirchhoff M, Lenz S, Henkel KO, Frerich B, Holzhüter G, Radefeldt S, Gerber $T$ (2011) Lateral augmentation of the mandible in minipigs with a synthetic nanostructured hydroxyapatite block. J Biomed Mater Res B Appl Biomater 96:342-350.

21. Burg KJ, Porter S, Kellam JF (2000) Biomaterial developments for bone tissue engineering. Biomaterials 21:2347-2359.

22. Nandi SK, Roy S, Mukherjee P, Kundu B, De DK, Basu D (2010) Orthopaedic applications of bone graft \& graft substitutes: a review. Indian J Med Res 132:15-30.

23. Pek YS, Gao S, Arshad MS, Leck KJ, Ying JY (2008) Porous collagen-apatite 
Citation: Xu W, Spilker G, Weinand C (2015) Methodological Consideration of Various Intraosseous and Heterotopic Bone Grafts Implantation in Animal Models. J Tissue Sci Eng 6: 161. doi:10.4172/2157-7552.1000161

Page 6 of 8

nanocomposite foams as bone regeneration scaffolds. Biomaterials 29:43004305

24. Seebach C, Schultheiss J, Wilhelm K, Frank J, Henrich D (2010) Comparison of six bone-graft substitutes regarding to cell seeding efficiency, metabolism and growth behaviour of human mesenchymal stem cells (MSC) in vitro. Injury 41:731-738.

25. Chatterjea A, Renard AJ, Jolink C, van Blitterswijk CA, Boer JD. Streamlining the generation of an osteogenic graft by $3 \mathrm{D}$ culture of unprocessed bone marrow on ceramic scaffolds. J Tissue Eng Regen Med. 2011 Feb 21. [Epub ahead of print].

26. Seo BM, Sonoyama W, Yamaza T, Coppe C, Kikuiri T, Akiyama K, Lee JS, Shi S (2008) SHED repair critical-size calvarial defects in mice. Oral Dis 14:428-434.

27. Guskuma MH, Hochuli-Vieira E, Pereira FP, Rangel-Garcia Junior I, Okamoto R, Okamoto T, Magro Filho O (2010) Bone regeneration in surgically created defects filled with autogenous bone: an epifluorescence microscopy analysis in rats. J Appl Oral Sci 18:346-353.

28. Balaguer T, Boukhechba F, Clavé A, Bouvet-Gerbettaz S, Trojani C, Michiels JF, Laugier JP, Bouler JM, Carle GF, Scimeca JC, Rochet N (2010) Biphasic calcium phosphate microparticles for bone formation: benefits of combination with blood clot. Tissue Eng Part A 16:3495-3505.

29. Kruse A, Jung RE, Nicholls F, Zwahlen RA, Hämmerle CH, Weber FE (2011) Bone regeneration in the presence of a synthetic hydroxyapatite/silica oxidebased and a xenogenic hydroxyapatite-based bone substitute material. Clin Oral Implants Res 22:506-511.

30. San Miguel B, Kriauciunas R, Tosatti S, Ehrbar M, Ghayor C, Textor M, Weber FE (2010) Enhanced osteoblastic activity and bone regeneration using surfacemodified porous bioactive glass scaffolds. J Biomed Mater Res A 94:1023-1033.

31. Matsui K, Matsui A, Handa T, Kawai T, Suzuki O, Kamakura S, Echigo S (2010) Bone regeneration by octacalcium phosphate collagen composites in a dog alveolar cleft model. Int J Oral Maxillofac Surg 39:1218-1225.

32. von Wilmowsky C, Schwarz S, Kerl JM, Srour S, Lell M, Felszeghy E, Schlegel KA (2010) Reconstruction of a mandibular defect with autogenous, autoclaved bone grafts and tissue engineering: An in vivo pilot study. J Biomed Mater Res A 93:1510-1518.

33. Tabassum A, Meijer GJ, Walboomers XF, Jansen JA (2011) Biological limits of the undersized surgical technique: a study in goats. Clin Oral Implants Res 22:129-134.

34. Pearce AI, Richards RG, Milz S, Schneider E, Pearce SG (2007) Animal models for implant biomaterial research in bone: a review. Eur Cell Mater 13:1-10.

35. O'Loughlin PF, Morr S, Bogunovic L, Kim AD, Park B, Lane JM (2008) Selection and development of preclinical models in fracture-healing research. $\mathrm{J}$ Bone Joint Surg Am 90(Suppl 1):79-84.

36. Le Guehennec L, Goyenvalle E, Aguado E, Houchmand-Cuny M, Enkel B, Pile P, Daculsi G, Layrolle P (2005) Small-animal models for testing macroporous ceramic bone substitutes. J Biomed Mater Res B Appl Biomater 72:69-78.

37. Abshagen K, Schrodi I, Gerber T, Vollmar B (2009) In vivo analysis of biocompatibility and vascularization of the synthetic bone grafting substitute NanoBone ${ }^{\circledR}$. J Biomed Mater Res A 91:557-566.

38. Schimandle JH, Boden SD (1994) Spine update. Animal use in spinal research. Spine 19:2474-2477

39. Nunamaker DM (1998) Experimental models of fracture repair. Clin Orthop Relat Res 355 Suppl:S56-65.

40. Viateau V, Bensidhoum M, Guillemin G, Petite H, Hannouche D, Anagnostou $F$, Pélissier $P(2010)$ Use of the induced membrane technique for bone tissue engineering purposes: animal studies. Orthop Clin North Am 41:49-56.

41. Eid K, Zelicof S, Perona BP, Sledge CB, Glowacki J (2001) Tissue reactions to particles of bone-substitute materials in intraosseous and heterotopic sites in rats: discrimination of osteoinduction, osteocompatibility, and inflammation. $J$ Orthop Res 19:962-969.

42. Viateau V, Logeart-Avramoglou D, Guillemin G, Petite H (2008) Animal models for bone tissue engineering purposes. Sourcebook of Models for Biomedical Research. Humana Press Inc., Totowa, NJ. 725-736.

43. Jang ES, Park JW, Kweon H, Lee KG, Kang SW, Baek DH, Choi JY, Kim SG (2010) Restoration of peri-implant defects in immediate implant installations by Choukroun platelet-rich fibrin and silk fibroin powder combination graft. Oral
Surg Oral Med Oral Pathol Oral Radiol Endod 109:831-836.

44. Araújo MV, Mendes VC, Chattopadhyay P, Davies JE (2010) Low-temperature particulate calcium phosphates for bone regeneration. Clin Oral Implants Res 21:632-641.

45. Oshima S, Ishikawa M, Mochizuki Y, Kobayashi T, Yasunaga Y, Ochi $M$ (2010) Enhancement of bone formation in an experimental bony defect using ferumoxide-labelled mesenchymal stromal cells and a magnetic targeting system. J Bone Joint Surg Br 92:1606-1613.

46. Keriquel V, Guillemot F, Arnault I, Guillotin B, Miraux S, Amédée J, Fricain JC Catros S (2010) In vivo bioprinting for computer- and robotic-assisted medical intervention: preliminary study in mice. Biofabrication 2:014101.

47. Schmitz JP, Hollinger JO (1986) The critical size defect as an experimenta model for craniomandibulofacial nonunions. Clin Orthop Relat Res 205:299308 .

48. Srouji S, Ben-David D, Müller R, Kohler T, Zussman E, Livne E (2011) A model for tissue engineering applications - femoral critical size defect in immunodeficient mice. Tissue Eng Part C Methods 17:597-606.

49. Obenaus $A$, Hayes $P$ (2011) Drill hole defects: induction, imaging, and analysis in the rodent. Methods Mol Biol 690:301-314.

50. Hansen T, Clermont G, Alves A, Eloy R, Brochhausen C, Boutrand JP, Gatt AM, Kirkpatrick CJ (2006) Biological tolerance of different materials in bulk and nanoparticulate form in a rat model: sarcoma development by nanoparticles. J R Soc Interface 3:767-775.

51. Kusumoto K, Bessho K, Fujimura K, Akioka J, Okubo Y, Ogawa Y, lizuka T (2000) The effect of blood supply in muscle and an elevated muscle flap on endogenous tissue-engineered bone by rhBMP-2 in the rat. Ann Plast Surg 45:408-414.

52. Bölgen N, Vargel I, Korkusuz P, Güzel E, Plieva F, Galaev I, Matiasson B, Pişkin $E$ (2009) Tissue responses to novel tissue engineering biodegradable cryogel scaffolds: an animal model. J Biomed Mater Res A 91:60-68.

53. Xu W, Holzhüter G, Sorg H, Wolter D, Lenz S, Gerber T, Vollmar B (2009) Early matrix change of a nanostructured bone grafting substitute in the rat. J Biomed Mater Res B Appl Biomater. 91:692-699.

54. Fraser JK, Wulur I, Alfonso Z, Hedrick MH (2006) Fat tissue: an underappreciated source of stem cells for biotechnology. Trends Biotechnol 24:150-154.

55. Bülow J (2001) Measurement of adipose tissue blood flow. Methods Mol Biol 155:281-293.

56. Hartman EH, Vehof JW, de Ruijter JE, Spauwen PH, Jansen JA (2004) Ectopic bone formation in rats: the importance of vascularity of the acceptor site. Biomaterials 25:5831-5837.

57. Bergsma JE, Bos RRM, Rozema FR, Jong W, Boering G (1998) Biocompatibility of intraosseously implanted predegraded poly(lactide): an animal study. Journal of Materials Science: Materials in Medicine. 7:1-7.

58. Drosse I, Volkmer E, Seitz S, Seitz H, Penzkofer R, Zahn K, Matis U, Mutschle W, Augat P, Schieker M (2008) Validation of a femoral critical size defect model for orthotopic evaluation of bone healing: a biomechanical, veterinary and trauma surgical perspective. Tissue Eng Part C Methods 14:79-88.

59. Muschler GF, Raut VP, Patterson TE, Wenke JC, Hollinger JO (2010) The design and use of animal models for translational research in bone tissue engineering and regenerative medicine. Tissue Eng Part B Rev 16:123-145.

60. Luca L, Rougemont AL, Walpoth BH, Boure L, Tami A, Anderson JM, Jordan O, Gurny R (2011) Injectable rhBMP-2-loaded chitosan hydrogel composite: osteoinduction at ectopic site and in segmental long bone defect. J Biomed Mater Res A 96:66-74.

61. Morisue $\mathrm{H}$, Matsumoto $\mathrm{M}$, Chiba $\mathrm{K}$, Matsumoto $\mathrm{H}$, Toyama $\mathrm{Y}$, Aizawa $\mathrm{M}$ Kanzawa N, Fujimi TJ, Uchida H, Okada I (2009) Novel apatite fiber scaffolds can promote three-dimensional proliferation of osteoblasts in rodent bone regeneration models. J Biomed Mater Res A 90:811-818.

62. Yuan H, van Blitterswijk CA, de Groot K, de Bruijn JD (2006) Cross-species comparison of ectopic bone formation in biphasic calcium phosphate (BCP) and hydroxyapatite (HA) scaffolds. Tissue Eng 12:1607-1615.

63. Kang SW, Lee JS, Park MS, Park JH, Kim BS (2008) Enhancement of in vivo bone regeneration efficacy of human mesenchymal stem cells. J Microbiol Biotechnol 18:975-982. 
Citation: Xu W, Spilker G, Weinand C (2015) Methodological Consideration of Various Intraosseous and Heterotopic Bone Grafts Implantation in Animal Models. J Tissue Sci Eng 6: 161. doi:10.4172/2157-7552.1000161

Page 7 of 8

64. Morisue $\mathrm{H}$, Matsumoto $\mathrm{M}$, Chiba $\mathrm{K}$, Matsumoto $\mathrm{H}$, Toyama $\mathrm{Y}$, Aizawa $\mathrm{M}$, Kanzawa N, Fujimi TJ, Uchida H, Okada I (2009) Novel apatite fiber scaffolds can promote three-dimensional proliferation of osteoblasts in rodent bone regeneration models. J Biomed Mater Res A 90:811-818.

65. Schliephake H, Weich HA, Dullin, Hefferan TE, Creemers LB, Maran A, Classic $\mathrm{KL}$, Dhert WJ, Yaszemski MJ (2008) Retention of in vitro and in vivo BMP2 bioactivities in sustained delivery vehicles for bone tissue engineering. Biomaterials 29:3245-3252.

66. Kan L, Hu M, Gomes WA, Kessler JA (2004) Transgenic mice overexpressing BMP4 develop a fibrodysplasia ossificans progressiva (FOP)-like phenotype. Am J Pathol 165:1107-1115.

67. Urist MR, Silverman BF, Büring K, Dubuc FL, Rosenberg JM (1967) The bone induction principle. Clin Orthop Relat Res 53:243-283.

68. Urist MR, Mikulski AJ (1979) A soluble bone morphogenetic protein extracted from bone matrix with a mixed aqueous and nonaqueous solvent. Proc Soc Exp Biol Med 162:48-53

69. Levi B, James AW, Nelson ER, Vistnes D, Wu B, Lee M, Gupta A, Longaker MT. Human adipose derived stromal cells heal critical size mouse calvarial defects. PLoS One 2010;5:e11177.

70. Koh JT, Zhao Z, Wang Z, Lewis IS, Krebsbach PH, Franceschi RT (2008) Combinatorial gene therapy with BMP2/7 enhances cranial bone regeneration. J Dent Res 87:845-849.

71. Weinand C, Pomerantseva I, Neville CM, Gupta R, Weinberg E, Madisch I, Shapiro F, Abukawa H, Troulis MJ, Vacanti JP (2006) Hydrogel-beta-TCP scaffolds and stem cells for tissue engineering bone. Bone 38:555-563.

72. Lohfeld S, Barron V, McHugh PE (2005) Biomodels of Bone. a review. Ann Biomed Eng 33:1295-1311.

73. Schliephake H, Weich HA, Dullin C, Gruber R, Frahse S (2008) Mandibular bone repair by implantation of rhBMP-2 in a slow release carrier of polylactic acid--an experimental study in rats. Biomaterials 29:103-110.

74. Lim HC, Song KH, You H, Lee JS, Jung UW, Kim SY, Choi SH. Effectiveness of biphasic calcium phosphate block bone substitutes processed using a modified extrusion method in rabbit calvarial defects. J Peridontol Implant Sci 2015; 45 46 - 55 Blocks of HA:ß-TCP of various in concentrations in rabbit calvarial defects

75. Stevens MM (2008) Biomaterials for bone tissue engineering. Materials Today $11: 18-25$.

76. Weinand C, Nabili A, Khumar M, Dunn JR, Ramella-Roman J, Jeng JC, Jordan $\mathrm{MH}$, Tabata Y (2011) Factors of Osteogenesis Influencing Various Human Stem Cells on Third-Generation Gelatin/ $\beta$-Tricalcium Phosphate Scaffold Material. Rejuvenation R Sciadini MF es 14:185-94.

77. Okanoue $\mathrm{Y}$, Ikeuchi M, Takemasa R, Tani T, Matsumoto T, Sakamoto M, Nakasu M (2012) Comparison of in vivo bioactivity and compressive strength of a novel superporous hydroxyapatite with beta-tricalcium phosphates. Arch Orthop Trauma Surg 132: 1603 - 1610

78. Patel ZS, Yamamoto M, Ueda H, Tabata Y, Mikos AG (2008) Biodegradable gelatin microparticles as delivery systems for the controlled release of bone morphogenetic protein-2. Acta Biomater 4:1126-1138.

79. Jiang Y, Zhao J, Augat P, Ouyang X, Lu Y, Majumdar S, Genant HK (1998) Trabecular bone mineral and calculated structure of human bone specimens scanned by peripheral quantitative computed tomography: relation to biomechanical properties. J Bone Miner Res. 13:1783-1790.

80. Rho JY, Hobatho MC, Ashman RB (1995) Relations of mechanical properties to density and CT numbers in human bone. Med Eng Phys 17:347-355.

81. Korkusuz F, Akin S, Akkus O, Korkusuz P (2000) Assessment of mineral density and atomic content of fracture callus by quantitative computerized tomography. J Orthop Sci 5:248-255

82. Ardeshirylajimi A, Farhadian S, Adegani FJ, Mirzaei S, Zomorrod MS, Langroud L, Doostmohammadi A, Seyedjafari E, Soleimani M (2015) Enhanced osteoconductivity of polyethersulphone nanofibres loaded with bioactive glass nanoparticles in in vitro and in vivo models. Cell Prolif 48: $455-464$

83. Komlev VS, Popov VK, Mironov AV, Fedotov AY, Teterina AY, Smirnov IV, Bozo IY, Rybko VA, Deev RV (2015) 3D Printing of Octeocalcium Phosphate Bone Substitutes. Front Bioeng Biotechnol 8, 3: 81

84. Yang Y, Wu J, Jin G, Li L, Li Z, Li C (2015) Research of osteoblastic induced rat bone marrow mesenchymal stem cells cultured on $B$-TCP/PLLA porous scaffold. Int J Clin Exp Med 8: 3202 - 3209

85. Chen Z, Yuen J, Crawford R, Chang J, Wu C, Xiao Y (2015) The effect of osteoimmunomodulation on osteogenic effects of cobalt incorporated ß-tricalcium phosphate. Biomaterials 61: $126-138$

86. Gabbai-Armelin PR, Souza MT, Kido HW, Tim CR, Bossini PS, Magri AM, Fernandes KR, Pastor FA, Zanotto ED, Parizotto NA, Peitl O, Renno AC (2015). Effect of bioactive fibrous glassy scaffold on bone repair. J Mater Sci Mater Med 2015; 26: 177

87. David F, Levingstone T, Schneeweiss W, de Swarte M, Jahns H, Gleeson JP, O'Brian FJ (2015). Enhanced bone healing using collagen-hydroxyapatite scaffold implantation in the treatment of a large multiloculated mandibula aneurysmal bone cyst in a thoroughbread filly. J Tissue Eng Regen Med 9 : $1193-1199$

88. Villa MM, Wang L, Huang J, Row DW, Wei M (2015) Bone tissue engineering with a collagen-hydroxyapatite scaffold and cultured expanded bone stromal cells. J Biomed Mater Res B Appl Biomat 2015; 103: 243 - 253

89. Liu T, Wu G, Zheng Y, Wismeijer D, Everts V, Liu Y (2014). Cell-mediated BMP2 release from a novel dual-drug delivery system promotes bone formation. $\mathrm{Cli}$ Oral Implants Res. 2014; 25: 1412 - 1421

90. Yang S, Xu S, Zhou P, Wang J, Tan H, Liu Y, Tang TT, Liu CS (2014) Siliceous mesostructured cellular foams/poly(3-hydroxybutyrate-co-3-hydroxyhexanoate) composite biomaterials for bone regeneration. Int J Nanomedicine 2014; 20 : $4795-4807$

91. Jebahi S, Ben Saleh G, Saoudi M, Besaleh S, Oudadesse H, Mhadbi M, Rebai T, Keskes H, El Feki A (2014). Genotoxicity effect, antioxidant and biomechanical correlation: experimental study of agarose-chitosan bone graft substitute in New Zealand white rabbit model. Proc Inst Mech Eng H 228: 800 - 809

92. Lee JH, Ryu MY, Baek HR, Seo JH, Lee KM, Lee JH (2014). Generation of an rhBMP-2-loaded beta-tricalcium phosphate/hydrogel composite and evaluation of its efficacy on peri-implant bone formation. Biomed Mater 9: 055002

93. Cushnie EK, Ulery BD, Nelson SJ, Deng M, Sethuraman S, Doty SB, Lo KWH Khan YM, Laurencin CT (2014). Simple signaling molecules for inductive bone regenerative engineering. PLOS one 9: e101627

94. Seol YJ, Park JW, Jung JW, Jang J, Girdhari R, Kim SW, Cho DW (2014) Improvement of bone regeneration capability of ceramic scaffolds by accelerated release of their calcium ions. Tissue Eng Part A 2014; 20: 2840 $-2849$

95. Nguyen TB, Lee BT (2014) A combination of biphasic calcium phosphate scaffold with hyaluronic acid-gelatin hydrogel as a new tool for bone regeneration. Tissue Eng Part A 20: 1993 - 2004

96. Elgali I, Igawa K, Palmquist A, Lenneras M, Xia W, Coi S, Chung UI, Omar O, Thompson P (2014) Molecular and structural patterns of bone regeneration in surgically created defects containing bone substitutes. Biomaterials 35: 3229 $-3242$

97. Tayton E, Purcell M, Aarvold A, Smith JO, Briscoe A, Kanczler JM, Shakesheff KM, Howdle SM, Dunlop DG, Oreffo RO (2014) A comparison of polymer and polymer-hydroxyapatite composite tissue engineered scaffolds for use in bon e regeneration. Am in vitro and in vivo study. J Biomed Mater Res A 102: 2613 $-2624$

98. Zhang J, Zhou H, Yang K, Yuan Y, Liu C (2013) Rh BMP-2 loaded calcium silicate/ calcium phosphate cement scaffold with hierarchically porous structure for enhanced bone tissue regeneration. Biomaterials 34: 9381 - 9392

99. Nandi SK, Kundu B, Basu D (2013) Protein growth factors loaded highly porous chitosan scaffold: a comparison of bone healing properties. Mater Sci Eng C Mater Biol Appl 33: 1267 - 1275

100.Xiao W, Fu H, Rahaman MN, Liu Y, Bal BS (2013) Hollow hydroxyapatite microspheres: a novel bioactive and oetsoconductive carrier for controlled release of bone morphogenic protein-2 in bone regeneration. Acta Biomater 9: $8374-8383$

101. Linh NT, Lee KH, Lee BT (2013) Functional nanofiber mat of polyvinyl alcohol/ gelatin containing nanoparticles of biphasic calcium phosphate for bone regeneration in rat calvarial defects. J Biomed Mater Res A 101: 2412 - 2423

102. Tamimi F, Comeau P, Le Dihouannen D, Zhang YL, Bassett DC, Khalilil S Gbureck U, Tran SD, Komarova S, Barralet JE (2013) Perfluorodecalin and bone regeneration. Eur Cell Mater 25: $22-36$ 
Citation: Xu W, Spilker G, Weinand C (2015) Methodological Consideration of Various Intraosseous and Heterotopic Bone Grafts Implantation in Animal Models. J Tissue Sci Eng 6: 161. doi:10.4172/2157-7552.1000161

103. Liu X, Rahaman MN, Fu Q (2013) Bone regeneration in strong porous bioactive glass (13-93) scaffolds with an oriented microstructure implanted in rat calvarial defects. Acta Biomater 9: 4889 - 4898

104. Cao L, Duan PG, Whang HR, Li XL, Yuan FL, Fan ZY, Li SM, Dong J (2012) Degradation and osteogenic potential of a novel poly(lactic acid)/nano-sized ß-tricalcium phosphate scaffold. Int J Nanomedicine 7: 5881

105. Yang HL, Zhu XS, Chen L, Chen CM, Mangham DC, Coulton LA, Aiken SS (2012) Bone healing response to a synthetic calcium sulphate/ß-tricalcium phosphate graft material in a sheep vertebral body defect model. J Biomed Mat Res B Appl Biomater 100: 1911 - 1921

106. Schofer MD, Tünnemann L, Kaiser H, Roessler PP, Theisen C, Heverhagen JT, Hering J, Voelker M, Agarwal S, Efe T, Fuchs-Winkelmann S, Paletta JR (2012) Functionalisation of PLLA nanofiber scaffolds using a possible cooperative effect between collagen type I and BMP-2: impact on colonization and bone formation. J Mater Sci Mater Med 23: 2227 - 2233

107. Ghanaati S, Orth C, Barbeck M, Willershausen I, Thimm BW, Booms P Stübinger S, Landes C, Sader RA, Kirkpatrick CJ (2010) Histological and histomorphometrical analysis of a silica matrix embedded nanocrystalline hydroxyapatite bone substitute using the subcutaneous implantation model in Wistar rats. Biomed Mater 5:035005.

108. Brook IM, Craig GT, Hatton PV, Jonck LM (1992) Bone cell interactions with a granular glass-ionomer bone substitute material: in vivo and in vitro culture models. Biomaterials 13:721-725.

109. Kontaxis A, Abu-Serriah M, Ayoub AF, Barbenel JC (2004) Mechanical testing of recombinant human bone morphogenetic protein-7 regenerated bone in sheep mandibles. Proc Inst Mech Eng H 218:381-388.

110. Sciadini MF, Dawson JM, Johnson KD (1997) Evaluation of bovine-derived bone protein with a natural coral carrier as a bone-graft substitute in a canine segmental defect model. J Orthop Res 15:844-857.

111. Arinzeh TL, Peter SJ, Archambault MP, van den Bos C, Gordon S, Kraus K Smith A, Kadiyala S. Allogeneic mesenchymal stem cells regenerate bone in a critical-sized canine segmental defect. J Bone Joint Surg Am 2003;85-A:19271935.

112. Rai B, Ho KH, Lei Y, Si-Hoe KM, Jeremy Teo CM, Yacob KB, Chen F, Ng
FC, Teoh SH (2007) Polycaprolactone-20\% tricalcium phosphate scaffolds in combination with platelet-rich plasma for the treatment of critical-sized defects of the mandible: a pilot study. J Oral Maxillofac Surg 65:2195-2205.

113. Taga ML, Granjeiro JM, Cestari TM, Taga R (2008) Healing of critical-size cranial defects in guinea pigs using a bovine bone-derived resorbable membrane. Int J Oral Maxillofac Implants 23:427-436.

114. Henkel KO, Gerber T, Lenz S, Gundlach KK, Bienengraeber V (2006) Macroscopical, histological, and morphometric studies of porous bonereplacement materials in minipigs 8 months after implantation. Oral Surg Oral Med Oral Pathol Oral Radiol Endod 102:606-613.

115. Bodde EW, Cammaert CT, Wolke JG, Spauwen PH, Jansen JA (2007) Investigation as to the osteoinductivity of macroporous calcium phosphate cement in goats. J Biomed Mater Res B Appl Biomater 83:161-168.

116. Sun JS, Chen PY, Tsuang YH, Chen MH, Chen PQ (2009) Vitamin-D binding protein does not enhance healing in rat bone defects: a pilot study. Clin Orthop Relat Res 467:3156-3164.

17. Kamegai A, Shimamura N, Naitou K, Nagahara K, Kanematsu N, Mori M (1994) Bone formation under the influence of bone morphogenetic protein self-setting apatite cement composite as a delivery system. Biomed Mater Eng 4:291-307.

118. Pluhar GE, Turner AS, Pierce AR, Toth CA, Wheeler DL (2006) A comparison of two biomaterial carriers for osteogenic protein-1 (BMP-7) in an ovine critical defect model. J Bone Joint Surg Br 88:960-966.

119. Viljanen VV, Lindholm TC, Gao TJ, Lindholm TS (1997) Low dosage of native allogeneic bone morphogenetic protein in repair of sheep calvarial defects. Int J Oral Maxillofac Surg 26:389-393.

120. Den Boer FC, Wippermann BW, Blokhuis TJ, Patka P, Bakker FC, Haarman HJ (2003) Healing of segmental bone defects with granular porous hydroxyapatite augmented with recombinant human osteogenic protein-1 or autologous bone marrow. J Orthop Res 21:521-528

121. Kempen DH, Lu L, Hefferan TE, Creemers LB, Maran A, Classic KL, Dhert WJ, Yaszemski MJ (2008) Retention of in vitro and in vivo BMP-2 bioactivities in sustained delivery vehicles for bone tissue engineering. Biomaterials 29:32453252. 